\title{
MATERIAL EMBODIMENT AND ENERGY FLOWS AS EFFICIENCY INDICATORS OF SOYBEAN (Glycine max) PRODUCTION IN BRAZIL
}

\section{THIAGO L. ROMANELLI ${ }^{1}$, HUDSON DE S. NARDI ${ }^{2}$, FILIPE A. SAAD ${ }^{3}$}

\begin{abstract}
As the requirement for agriculture to be environmentally suitable there is a necessity to adopt indicators and methodologies approaching sustainability. In Brazil, biodiesel addition into diesel is mandatory and soybean oil is its main source. The material embodiment determines the convergence of inputs into the crop. Moreover, the material flows are necessary for any environmental analysis. This study evaluated distinct production scenarios, and also conventional versus GMO crops, through the material embodiment and energy analysis. GMO crops demanded less indirectly applied inputs. The energy balance showed linearity with yield, whereas for EROI, the increases in input and yield were not affected.
\end{abstract}

KEYWORDS: production systems, GMO, environmental management, energy balance, EROI.

\section{INCORPORAÇÃO MATERIAL E FLUXOS DE ENERGIA COMO INDICADORES DE EFICIÊNCIA DA PRODUÇÃO DE SOJA (Glycine max) NO BRASIL}

RESUMO: Para a agricultura alcançar os patamares de sustentabilidade ambiental, é fundamental a adoção de indicadores e metodologias que a tornem viável. No Brasil, a adição de biodiesel ao diesel foi estabelecida em lei, sendo que a principal fonte para a obtenção desse biocombustível é o óleo de soja. A incorporação de material determina a convergência das entradas de produtos e serviços dentro de uma cultura agrícola. Além disso, a avaliação dos fluxos de materiais é necessária para qualquer análise ambiental. Este trabalho procura avaliar diferentes cenários produtivos e também comparar os cultivos de soja convencional e geneticamente modificada (OGM), através da incorporação material e da análise de energia nos sistemas. O uso de OGM demandou menores inputs indiretamente aplicados ao sistema. $\mathrm{O}$ balanço energético mostrou linearidade com a produtividade, enquanto para o EROI, o crescimento nos inputs e na produtividade não foram afetados.

PALAVRAS-CHAVE: sistemas de produção, OGM, manejo ambiental, balanço energético, EROI.

\section{INTRODUCTION}

Agricultural systems are economic, thermodynamic and physical entities, subject simultaneously to the constraints of all these aspects. So, for planning and assessment of agricultural operations, both economic and non-economic factors must be considered, necessitating a system view (TELLARINI \& CAPORALI, 2000). Although there are studies approaching economical and environmental aspects of biomass and bioenergy sources (RANIUSA et al., 2005; DIAZ-BALTEIRO \& RODRIGUEZ, 2006) there is little information about their energy and material approach (CHAVANNE \& FRANGI, 2008; PIMENTEL \& PATZEK, 2005; PIMENTEL et al., 2005). As the requirement for agricultural sector to be environmentally suitable (JACOVINE et al., 2009), there is a necessity to adopt proper indicators and methodologies approaching sustainability.

In Brazil, biodiesel is mandatory by law to be added in diesel oil (B4 since July 2009, and 5\% in 2013 according to the Law 11.097). Currently 1.2 million $\mathrm{m}^{3}$ are produced and soybean oil is the

\footnotetext{
${ }^{1}$ Eng$^{\mathrm{o}}$ Agrônomo, Professor Doutor da ESALQ/USP, Piracicaba - SP, Fone: (0XX19) 34294165, romanelli@ usp.br.

${ }^{2}$ Eng ${ }^{\circ}$ Agrícola, Analista/CPAFAC/Embrapa, Rio Branco - AC, Fone: (0XX68) 3212-3281, hudsonnardi@ yahoo.com.br.

${ }^{3}$ Eng $^{\mathrm{O}}$ Agrônomo, Mestrando em Engenharia de Sistemas Agrícolas, ESALQ/USP, Piracicaba - SP, Fone: (0XX19) 3429.4165, filipesaad22@hotmail.com.
}

Recebido pelo Conselho Editorial em: 26-1-2011

Aprovado pelo Conselho Editorial em: 9-11-2011 
main source (85\%), followed by animal fat (11\%) and cotton seed oil (2\%) (ANP, 2009). Soybean was grown in 21 million ha and the national production reached 57 million $\mathrm{Mg}$ in 2008 (IBGE, 2007). Just as PIMENTEL (1980) showed for corn production, it is necessary to determine the energy optimum management. So, it can be compared to the economic and yield optimums. Material flow is the basis of cost determination, since every single input multiplied by their price determines cost and also, most of the methodologies used to environmentally assess production systems are based on material flows (ROMANELLI \& MILAN, 2010a), such as energy analyses (CHAVANNE \& FRANGI, 2008; PIMENTEL \& PATZEK, 2005; PIMENTEL et al., 2005). The evaluation of how production systems demand and supply energy is vital (ROMANELLI \& MILAN, 2005). Energy analyses establish flows; identify the total demand, the net gain and the return over the invested energy, besides the energy embodied in a product or service (CHAVANNE \& FRANGI, 2008; PIMENTEL \& PATZEK, 2005; PIMENTEL et al., 2005, ROMANELLI et al., 2008). One considers as input energy not only the applied sources (electricity, fuels), but also the energy embodied into the input production and services. This study aimed to evaluate distinct production regions in Brazil and distinct technological means (conventional and genetically modified seed - GMO) for the material and energy embodiment.

\section{MATERIAL AND METHODS}

Nine distinct scenarios were evaluated representing the more important states where soybean is produced in Brazil. Four regions were approached: South region, with Rio Grande do Sul (RS) and Paraná (PR); Middle-west region, with Mato Grosso (MT), Mato Grosso do Sul (MS) and Goiás (GO); Southeast region, with São Paulo (SP) and Minas Gerais (MG); and Northeast region, with Bahia (BA) and Maranhão (MA). The data were collected in an annual publication focused on production cost (AGRIFNP, 2009). Although, it does not approach material and energy aspects, they provide data for them to be determined.

Regarding material flows, there are two kinds of flows: the directly applied inputs and the indirectly applied inputs. So, in this section, it is shown the steps for the material flows to be determined, as follows: 1) Adoption of a diagram language to represent the analyzed system; 2) Determination of the material flows of directly applied inputs; 3) Determination of the material flows of indirectly applied inputs. The latter includes: effective field capacity; fuel consumption; machinery depreciation; and labor.

\section{Diagram methodology}

Considering ecology and energy, H.T. Odum developed the Energy Language System (ROMANELLI \& MILAN, 2010a), which brings the advantage of determining the boundaries of the studied system, i.e., the flows that cross the boundaries and that are quantified are previously shown to the readers. In this language, there are symbols for storage (e.g., soil in agriculture), producers (plants), consumers (animals), transactions (money versus goods/service), interaction (e.g., mechanization is an interaction of labor, machinery depreciation, fuel consumption and the input applied), heat sink which represents entropy generation (only applied when using the language to represent energy flows), constant force source (rain, wind), flow limited source (sunlight due to the refraction in the atmosphere).

The system diagram shows the steps taken for the establishment of the material flows through mechanized operations, which depend on the inputs applied indirectly (machinery, irrigation systems, labor, and fuel) and directly (fertilizers, lime, pesticides, seeds, seedlings).

The flows of machinery (irrigation systems as well) feed the asset stock, since assets are depreciated as the mechanized operations and the irrigation are performed. They have a useful life, i.e., a period when they will provide services and after this period they are replaced. For instance, $4 \times 2$ tractors present a useful life around 12,000 hours, which, of course varies according to the maintenance provided and the use intensity. Fuel (or electricity for irrigation) is necessary for the assets to run as well as labor. 


\section{Determination of the material flows of directly applied inputs}

The flow of directly applied inputs is determined by technical prescription, the application rate (volume, mass or quantity per area) already is the material flow. Prescription, in this case, is just a simplification of the decision making process, since fertilizer application, for instance, can be determined by soil analyses, by the crop's physiological status or by a sensor (precision farming) that may apply models that are outside the boundaries established. The data about the production systems are those presented by AGRIFNP (2009); whose annual publication brings the production cost of the main crops in Brazil, which is determined by quantity of each input consumed (e.g.: $\left.\mathrm{h} \mathrm{ha}^{-1}, \mathrm{~kg} \mathrm{ha}^{-1}, \mathrm{~L} \mathrm{ha}^{-1}\right)$ and their prices $\left(\$ \mathrm{~h}^{-1}, \$ \mathrm{~kg}^{-1}, \$ \mathrm{~L}^{-1}\right)$.

\section{Determination of the material flows of indirectly applied inputs}

Machinery, labor and fuel consumption are not provided by AGRIFNP (2009). The data provided for each mechanized operation were the power of the tractor engine and the field capacity. The latter is indirectly determined by the inversion of the time demanded for the machinery performs its work in one hectare. The determination of the material flows of indirectly applied inputs depends on the determination of labor, machinery depreciation and fuel consumption in area basis such as the directly applied inputs.

\section{Effective field capacity}

Effective field capacity is the amount of area per time that the agricultural machinery actually performs. When these data are not available, it can be calculated (eq.(1)) when one knows the dimension of the implement (work width), the work speed and the typical efficiency (ASAE, 2003). The effective field capacity is important for the flows to be adjusted in area basis, since generally the data (e.g. fuel consumption) is usually obtained in time basis.

$$
\mathrm{EFC}=(\mathrm{S} \text { W FE }) / 10
$$

Where,

EFC - effective field capacity, ha $\mathrm{h}^{-1}$;

$\mathrm{S}$ - work speed, $\mathrm{km} \mathrm{h}^{-1}$;

W - work width, m;

FE - field efficiency, decimal.

\section{Fuel consumption}

For the determination of fuel consumption in a mechanized operation it was used a factor which applies power as a continuous variable, through the specific consumption and engine power, as adopted by MOLIN \& MILAN (2002) (eq.(2)).

$$
\mathrm{C}_{\mathrm{Hour}}=\mathrm{GP}_{\mathrm{ENG}} \mathrm{SC}
$$

Where,

$\mathrm{C}_{\text {Hour }}$ - hourly consumption, $\mathrm{L} \mathrm{h}^{-1}$;

$\mathrm{GP}_{\mathrm{ENG}}$ - gross engine power, $\mathrm{kW}$;

$\mathrm{SC}$ - specific consumption, $0.163 \mathrm{~L} \mathrm{~kW}^{-1} \mathrm{~h}^{-1}$.

For a more detailed estimation, there is the methodology proposed by ASAE standard D497.4 (ASAE, 2003). In this model, the specific consumption $\left(\mathrm{L} \mathrm{kW}^{-1} \mathrm{~h}^{-1}\right)$ is given by the ratio of the power required by the implement and the power available at the tractor's PTO (power take-off).

\section{Machinery depreciation and labor}

The machinery physical depreciation is based on the useful life and the mass of the machinery and on effective field capacity they perform in the mechanized operations. Labor is based in the number of workers in each operation and on the effective field capacity of the tractor-implement sets which are being used. For instance if there is a worker helping two tractor-implement set, its labor flow may be considered as 0.5 man in addition to the labor of the tractor driver. The determination of these material flows were done according to ROMANELLI \& MILAN (2010a). 


\section{Energy indices}

Through the analysis of energy flows, one can establish the energy flows, identify the total demand, determinate the energy performance that is reflected by the net gain and also by the ratio of energy made available over the invested. The indicators used to evaluate this performance are: energy balance (EB), EROI (energy return over investment) and energy intensity (EI). EB refers to the net energy gain per area, while EROI refers to the ratio of energy made available by the required energy in a process and it can be understood as "energy profitability". EI is the embodied energy per unit of the obtained product. EI is an important indicator for products which have no energetic use (e.g.: fiber). These indicators are determined through the energy input (EIF) and output (EOF) flows. For the EB to be determined (Equation 3), the energy input flow (EIF) is subtracted from the output flow (EOF), resulting in the net gain per area (ROMANELLI \& MILAN, 2010b; SILVA et al., 2010).

Some authors refer to the energy balance as the ratio of energy made available and the required by a production system. However, in this study for this ratio the term EROI (eq.(4)) was adopted.

$$
\begin{aligned}
& \mathrm{EB}=\mathrm{EOF}-\mathrm{EIF} \\
& \mathrm{EROI}=(\mathrm{EOF}-\mathrm{EIF}) / \mathrm{EIF}
\end{aligned}
$$

Where,

EB - energy balance, $\mathrm{MJ} \mathrm{ha}^{-1}$;

EIF - energy input flow, $\mathrm{MJ} \mathrm{ha}^{-1}$;

EOF - energy output flow, MJ ha'

EROI - energy return over investment, $\mathrm{MJ} \mathrm{MJ}^{-1}$.

The energy input flow is determined by multiplying the material flow and the energy embodied in the processes of obtaining them (Table 1). For the output energy flow (OEF), it was considered the potential oil in the grains, since the activities necessary to extract oil out of the grains are not into the scope of the present study. It was considered the oil content of $20 \%$ of the grain mass (MASUDA \& GOLDSMITH, 2009).

Considering the energy intensity of the harvested grains, the energy input flow can be related to the yield for the energy intensity (EI) to be determined (eq.(5)).

$$
\mathrm{EI}=\mathrm{EIF} / \mathrm{Y}
$$

Where,

EI - energy intensity, $\mathrm{MJ} \mathrm{kg}^{-1}$;

$\mathrm{Y}$ - yield, $\mathrm{kg} \mathrm{ha}^{-1}$.

TABLE 1. Energy indices for agricultural inputs.

\begin{tabular}{ccrc}
\hline Input & Unit & $\begin{array}{c}\text { Energy index } \\
\text { MJ unit }^{-1}\end{array}$ & References \\
\hline Labor & $\mathrm{h}$ & 2.20 & FERRARO JUNIOR (1999) \\
Diesel & $\mathrm{L}$ & 38.60 & ULBANERE \& FERREIRA (1989) \\
Machinery & $\mathrm{kg}$ & 68.90 & ULBANERE \& FERREIRA (1989) \\
Limestone & $\mathrm{kg}$ & 1.67 & FERRARO JUNIOR (1999) \\
$\mathrm{N}$ & $\mathrm{kg}$ & 74.00 & PELLIZZI (1992) \\
$\mathrm{P}_{2} \mathrm{O}_{5}$ & $\mathrm{~kg}$ & 12.56 & FERRARO JUNIOR (1999) \\
$\mathrm{K}_{2} \mathrm{O}$ & $\mathrm{kg}$ & 6.70 & FERRARO JUNIOR (1999) \\
Seeds & $\mathrm{kg}$ & 20.40 & EMBRAPA (2006) \\
Other chemicals & $\mathrm{kg}$ & 184.70 & PIMENTEL (1980) \\
Fungicide & $\mathrm{L}$ & 97.13 & PIMENTEL (1980) \\
Herbicide & $\mathrm{L}$ & 454.20 & FLUCK \& BAIRD (1982) \\
Insecticide & $\mathrm{L}$ & 184.70 & PIMENTEL (1980)
\end{tabular}




\section{RESULTS AND DISCUSSION}

The soybean production system (Figure 1) depends on a resource basis which includes renewable environmental inputs (rainfall, wind and sunlight, represented by the evapotranspiration), natural stocks (soil), material stocks (machinery) and flows acquired in the market (fuels, $\mathrm{pH}$ management materials, seeds, seedlings, fertilizer, pesticides, new machinery and labor). There are interactions in mechanized operations aiming the crop establishment and maintenance and also in harvesting, where the product is obtained and released to the market.

One must emphasize that the diagram shows the natural resources, but they are not considered by energy analyses. Other methodologies, such as energy synthesis take them into account (CAVALETT et al, 2006; ROMANELLI et al, 2008; PIZZIGALLO et al, 2008). The energy sink represents the inefficiency of transformation process, such as heat generation in the engines or fertilizer that does not reach the roots, for instance.

The material convergence for the soybean fields are presented in Table 2. These data regard the conventional crop, without using genetically modified seeds. Material flows are hardly used for comparisons because it brings multi-criteria data. For instance, RS scenario uses less seed treatment than the MS (1.0 versus $\left.1.7 \mathrm{~L} \mathrm{ha}^{-1}\right)$ but it uses more $\mathrm{K}_{2} \mathrm{O}\left(50.0\right.$ versus $\left.48 \mathrm{~kg} \mathrm{ha}^{-1}\right)$. The decision maker has to know the circumstances of each scenario in order to properly evaluate if $0.8 \mathrm{~L} \mathrm{ha}^{-1}$ less herbicide is better or not that $5.1 \mathrm{~kg} \mathrm{ha}^{-1}$ more $\mathrm{P}_{2} \mathrm{O}_{5}$, for instance, in environmental terms or even in the logistics both inputs depend on. In order to account the effect of agricultural inputs into yield, the material embodiment was also determined per grain production (Table 3 ).

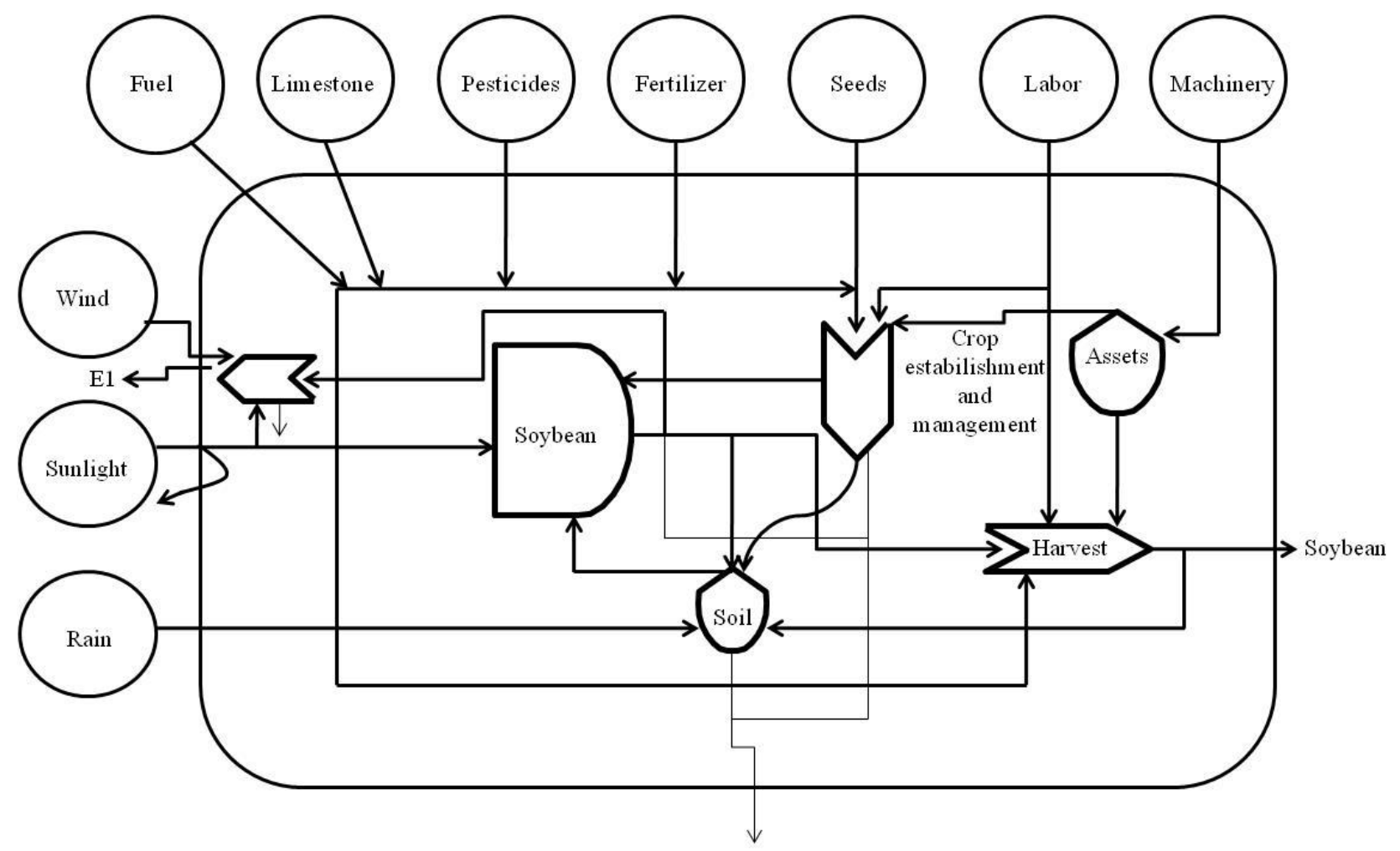

FIGURE 1. Representation of a soybean production system. 
TABLE 2. Material embodiment of soybean cropland in distinct scenarios.

\begin{tabular}{ccrrrrrrrrr}
\hline Inputs & unit & RS & MS & GO & PR & $\begin{array}{c}\text { MT } \\
\text { unit ha }\end{array}$ & BA & MG & MA & SP \\
\hline Labor & $\mathrm{h}$ & 5.4 & 5.9 & 5.9 & 5.0 & 6.0 & 5.8 & 5.0 & 4.3 & 3.6 \\
Diesel & $\mathrm{L}$ & 48.3 & 46.7 & 51.2 & 44.6 & 42.8 & 43.0 & 45.0 & 38.0 & 50.5 \\
Mach. Depr. & $\mathrm{kg}$ & 5.5 & 5.9 & 5.3 & 5.1 & 5.2 & 5.1 & 5.1 & 4.2 & 4.9 \\
Limestone & $\mathrm{kg}$ & 250.0 & 250.0 & 560.0 & 200.0 & 560.0 & 560.0 & 560.0 & 560.0 & 500.0 \\
$\mathrm{~N}$ & $\mathrm{~kg}$ & 0.0 & 0.0 & 0.0 & 0.0 & 0.0 & 0.0 & 8.0 & 8.0 & 5.0 \\
$\mathrm{P}_{2} \mathrm{O}_{5}$ & $\mathrm{~kg}$ & 50.0 & 48.0 & 72.0 & 48.0 & 64.0 & 80.0 & 80.0 & 80.0 & 50.0 \\
$\mathrm{~K}_{2} \mathrm{O}$ & $\mathrm{kg}$ & 50.0 & 48.0 & 54.0 & 48.0 & 64.0 & 80.0 & 80.0 & 80.0 & 50.0 \\
Seeds & $\mathrm{kg}$ & 65.0 & 70.0 & 70.0 & 65.0 & 60.0 & 65.0 & 60.0 & 65.0 & 75.0 \\
Seed treatment & $\mathrm{L}$ & 1.0 & 1.7 & 1.0 & 1.5 & 1.7 & 2.0 & 1.2 & 2.0 & 2.2 \\
Form./Acaricide & $\mathrm{L}$ & 0.5 & 0.5 & 0.2 & 0.0 & 0.2 & 0.2 & 1.0 & 1.0 & 0.3 \\
Fungicide & $\mathrm{L}$ & 1.2 & 1.1 & 1.1 & 1.1 & 1.1 & 1.1 & 1.2 & 1.2 & 1.2 \\
Herbicide & $\mathrm{L}$ & 3.2 & 6.1 & 5.5 & 5.5 & 5.0 & 5.0 & 4.5 & 3.5 & 3.9 \\
Insecticide & $\mathrm{L}$ & 0.6 & 0.6 & 1.0 & 2.2 & 0.6 & 0.6 & 0.6 & 0.2 & 2.1 \\
Other chemicals & $\mathrm{L}$ & 0.7 & 0.7 & 0.7 & 1.2 & 0.7 & 0.7 & 0.7 & 0.7 & 5.1 \\
Yield & $\mathrm{Mg} \mathrm{ha}^{-1}$ & 2,10 & 2,64 & 2,70 & 2,80 & 2,80 & 2,50 & 2,60 & 2.60 & 2,80 \\
\hline
\end{tabular}

The soybean produced in the SP scenario is the one that uses less labor, half of the most demanding (RS), what can be interpreted either as more work efficient or less social efficient depending on the focus the reader may have. RS uses more diesel oil and machinery depreciation, which would increase the carbon footprint of this scenario if this analysis were done. SP and PR used at least twice the insecticide compared to the other ones, but they are on the lowest fungicide consumption. Nitrogen was only used in three scenarios, since soybeans fix it if seeds are properly inoculated.

TABLE 3. Material embodiment of soybeans in distinct scenarios.

\begin{tabular}{ccrrrrrrrrr}
\hline Inputs & unit & RS & MS & GO & PR & $\begin{array}{c}\text { MT } \\
\text { unit } \mathrm{Mg}^{-1}\end{array}$ & BA & MG & MA & SP \\
\hline Labor & $\mathrm{h}$ & 2.6 & 2.2 & 2.2 & 1.8 & 2.1 & 2.3 & 1.9 & 1.7 & 1.3 \\
Diesel & $\mathrm{L}$ & 23.0 & 17.7 & 19.0 & 15.9 & 15.3 & 17.2 & 17.3 & 14.6 & 18.0 \\
Mach. Depr. & $\mathrm{kg}$ & 2.6 & 2.2 & 1.9 & 1.8 & 1.8 & 2.0 & 2.0 & 1.6 & 1.8 \\
Limestone & $\mathrm{kg}$ & 119.0 & 94.7 & 207.4 & 71.4 & 200.0 & 224.0 & 215.4 & 215.4 & 178.6 \\
$\mathrm{~N}$ & $\mathrm{~kg}$ & 0.0 & 0.0 & 0.0 & 0.0 & 0.0 & 0.0 & 3.1 & 3.1 & 1.8 \\
$\mathrm{P}_{2} \mathrm{O}_{5}$ & $\mathrm{~kg}$ & 23.8 & 18.2 & 26.7 & 17.1 & 22.9 & 32.0 & 30.8 & 30.8 & 17.9 \\
$\mathrm{~K}_{2} \mathrm{O}$ & $\mathrm{kg}$ & 23.8 & 18.2 & 20.0 & 17.1 & 22.9 & 32.0 & 30.8 & 30.8 & 17.9 \\
Seeds & $\mathrm{kg}$ & 31.0 & 26.5 & 25.9 & 23.2 & 21.4 & 26.0 & 23.1 & 25.0 & 26.8 \\
Seed treatment & $\mathrm{L}$ & 0.5 & 0.6 & 0.4 & 0.5 & 0.6 & 0.8 & 0.5 & 0.8 & 0.8 \\
Acaricide & $\mathrm{L}$ & 0.2 & 0.2 & 0.1 & 0.0 & 0.1 & 0.1 & 0.4 & 0.4 & 0.1 \\
Fungicide & $\mathrm{L}$ & 0.6 & 0.4 & 0.4 & 0.4 & 0.4 & 0.4 & 0.5 & 0.5 & 0.4 \\
Herbicide & $\mathrm{L}$ & 1.5 & 2.3 & 2.0 & 1.9 & 1.8 & 2.0 & 1.7 & 1.3 & 1.4 \\
Insecticide & $\mathrm{L}$ & 0.3 & 0.2 & 0.4 & 0.8 & 0.2 & 0.2 & 0.2 & 0.1 & 0.8 \\
Other chemicals & $\mathrm{L}$ & 0.3 & 0.3 & 0.3 & 0.4 & 0.3 & 0.3 & 0.3 & 0.3 & 1.8 \\
\hline
\end{tabular}

The material flows of GMO production systems were compared for each state (Table 4). The inputs where differences mainly occurred were the indirectly applied inputs (labor, machinery depreciation and diesel) because they are dependent on the amount of mechanization applied. In PR, fertilizer presented an application rate for $\mathrm{K}_{2} \mathrm{O} 50 \%$ higher than in the conventional system. BA scenario reduced $\mathrm{K}_{2} \mathrm{O}$ and $\mathrm{P}_{2} \mathrm{O}_{5}$ application in $20 \%$. The six scenarios which did not apply nitrogen in conventional crop, apply it on GMO soybean: RS, MS, GO, PR, MT and BA applied 5.0, 4.8, $7.2,4.8,6.4$ and $6.4 \mathrm{~kg} \mathrm{ha}^{-1}$, respectively. These values cannot be represented as a percent variation because it was not applied in the compared system. 
For the SP scenario the consumption of acaricide and insecticide increased (300\% and 33.3\%, respectively). The magnitude of $300 \%$ increase is due the application rate had increased from 0.25 to $1.0 \mathrm{~L} \mathrm{ha}^{-1}$, almost the same rate gradient of the insecticide from 2.1 to $2.8 \mathrm{~L} \mathrm{ha}^{-1}$. The data about the variation of the inputs used are either in area basis or mass basis since there was no difference of yields between conventional and GMO production.

TABLE 4. Variation of agricultural inputs use by adopting GMO technology.

\begin{tabular}{crrrrrrrrr}
\hline Input & RS & MS & GO & PR & $\begin{array}{l}\text { MT } \\
\%\end{array}$ & BA & MG & MA & SP \\
\hline Labor & -6.7 & -6.8 & -6.1 & -2.6 & -3.9 & -6.3 & 3.0 & -4.6 & -9.7 \\
Diesel & -9.1 & -10.1 & 7.6 & -1.4 & -6.6 & -9.8 & -1.6 & -6.2 & -15.1 \\
Machinery & -7.9 & -5.9 & 9.0 & -4.2 & -5.7 & -6.2 & -5.8 & -4.2 & -5.2 \\
$\mathrm{P}_{2} \mathrm{O}_{5}$ & $*$ & $*$ & $*$ & $*$ & $*$ & -20.0 & $*$ & $*$ & $*$ \\
$\mathrm{~K}_{2} \mathrm{O}$ & $*$ & $*$ & $*$ & 50.0 & $*$ & -20.0 & $*$ & $*$ & $*$ \\
Acaricide & $*$ & $*$ & $*$ & $*$ & $*$ & $*$ & $*$ & $*$ & 300.0 \\
Fungicide & $*$ & $*$ & $*$ & $*$ & $*$ & $*$ & -6.7 & $*$ & $*$ \\
Herbicide & 25.0 & -33.9 & -36.7 & -35.8 & -29.3 & -29.3 & -21.3 & 1.4 & -10.3 \\
Insecticide & $*$ & $*$ & $*$ & $*$ & $*$ & $*$ & $*$ & $*$ & 33.3 \\
\hline
\end{tabular}

Based on the material flows the input and output energy flows were determined as well the indicators energy balance, energy intensity and energy return over investment (Table 5). The data regarding the GMO production systems show also the variation in the energy indicators compared to the conventional systems. Excepting RS and GO scenarios, the energy indicators presented better results (higher EB and EROI and lower EI). This is due to the lower EIF presented by the scenarios, whose variation is the same as presented for the IE.

TABLE 5. Energy flows and indicators for conventional and GMO soybean systems.

\begin{tabular}{|c|c|c|c|c|c|c|c|c|}
\hline \multicolumn{9}{|c|}{ Conventional } \\
\hline & $\begin{array}{c}\text { EIF } \\
\text { MJ ha }^{-1}\end{array}$ & $\begin{array}{c}\text { EOF } \\
\text { MJ ha }^{-1}\end{array}$ & $\begin{array}{c}\text { EB } \\
\mathrm{MJ} \mathrm{ha}^{-1}\end{array}$ & & $\begin{array}{c}\text { EI } \\
\mathrm{MJ} \mathrm{kg}^{-1}\end{array}$ & \multicolumn{3}{|c|}{ EROI } \\
\hline $\mathrm{RS}$ & 6729 & 42840 & 36111 & & 3.20 & \multicolumn{3}{|c|}{5.37} \\
\hline MS & 8043 & 53856 & 45813 & & 3.05 & \multicolumn{3}{|c|}{5.70} \\
\hline GO & 8821 & 55080 & 46259 & & 3.27 & \multicolumn{3}{|c|}{5.24} \\
\hline PR & 7658 & 57120 & 49462 & & 2.74 & \multicolumn{3}{|c|}{6.46} \\
\hline MT & 7911 & 57120 & 49209 & & 2.83 & \multicolumn{3}{|c|}{6.22} \\
\hline BA & 8317 & 51000 & 42683 & & 3.33 & \multicolumn{3}{|c|}{5.13} \\
\hline MG & 8818 & 53040 & 44222 & & 3.39 & \multicolumn{3}{|c|}{5.02} \\
\hline MA & 8060 & 53040 & 44980 & & 3.10 & \multicolumn{3}{|c|}{5.58} \\
\hline SP & 8320 & 57120 & 48800 & & 2.97 & \multicolumn{3}{|c|}{5.87} \\
\hline \multicolumn{9}{|c|}{ GMO } \\
\hline & EIF & EOF & EB & & EI & \multicolumn{3}{|c|}{ EROI } \\
\hline & $\mathrm{MJ} \mathrm{ha}^{-1}$ & $\mathrm{MJ} \mathrm{ha}^{-1}$ & $\mathrm{MJ} \mathrm{ha}^{-1}$ & $\Delta \%$ & $\mathrm{MJ} \mathrm{kg}^{-1}$ & $\Delta \%$ & & $\Delta \%$ \\
\hline $\mathrm{RS}$ & 7262 & 42840 & 35578 & -1.5 & 3.5 & 7.3 & 4.9 & -9.5 \\
\hline MS & 7260 & 53856 & 46596 & 1.7 & 2.8 & -10.8 & 6.4 & 11.2 \\
\hline GO & 9327 & 55080 & 45753 & -1.1 & 3.5 & 5.4 & 4.9 & -6.9 \\
\hline PR & 7088 & 57120 & 50032 & 1.1 & 2.5 & -8.0 & 7.1 & 8.5 \\
\hline MT & 7596 & 57120 & 49524 & 0.6 & 2.7 & -4.1 & 6.5 & 4.6 \\
\hline BA & 7638 & 51000 & 43362 & 1.6 & 3.1 & -8.9 & 5.7 & 9.6 \\
\hline MG & 8330 & 53040 & 44710 & 1.1 & 3.2 & -5.9 & 5.4 & 6.6 \\
\hline MA & 7980 & 53040 & 45060 & 0.2 & 3.1 & -1.0 & 5.6 & 1.2 \\
\hline SP & 7992 & 57120 & 49128 & 0.7 & 2.9 & -4.1 & 6.1 & 4.6 \\
\hline
\end{tabular}

EROI represents the energy profitability of systems and showed better performance for GMO production systems in MS and BA, increasing in $11.2 \%$ and $9.6 \%$, respectively. The magnitude of 
variation in the energy balance was lower, but the gross value and the amount of land destined to soybean production may result in a significant energy saving. The variation in EROI and EB presented a positive correlation (Figure 2), showing that, although two scenarios did not follow the trend, there is an increase in both indicators when adopting GMO. One must highlight that this study considered any effect neither in the surrounding ecosystem nor in the final consumption. The boundary of this analysis is merely the agricultural production (Figure 1).

The EB data presented high correlation with yield (Figure 3), which can make the latter to be used as an indirect indicator of EB. For this statement to be accepted more broadly, one should test these indicators in others crops and other conditions and with significant repetitions. For EROI this did not happen, because the increases in input use are not straightly turned into yield increases. So, one can observe high EROI in less intensified crop management (RS). PR scenario presented the higher EROI and EB, posing as the best scenario energetically.

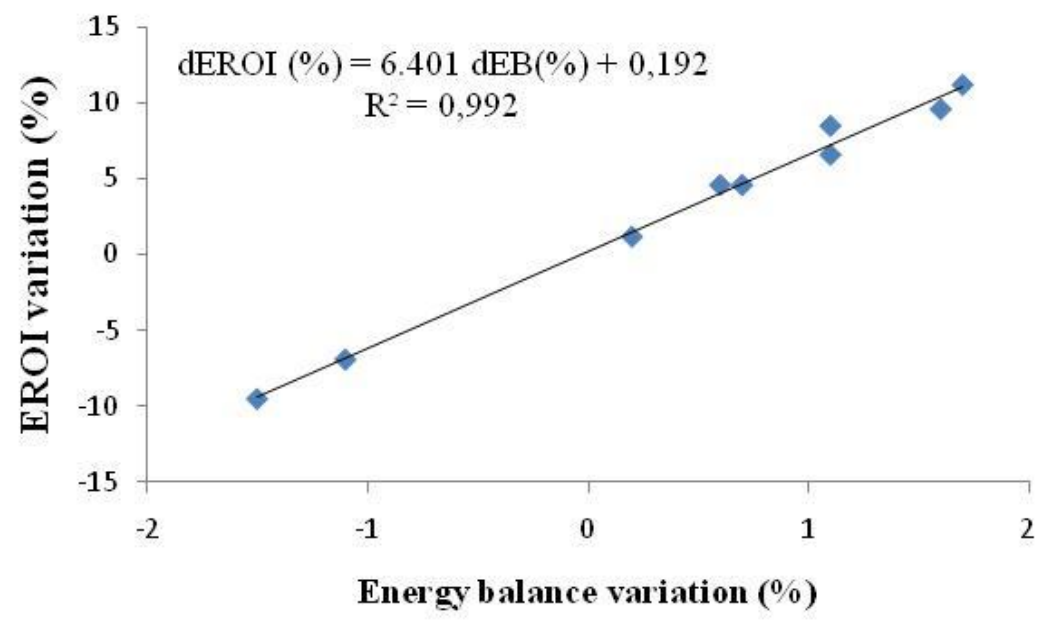

FIGURE 2. Behavior of variations in EB and EROI.

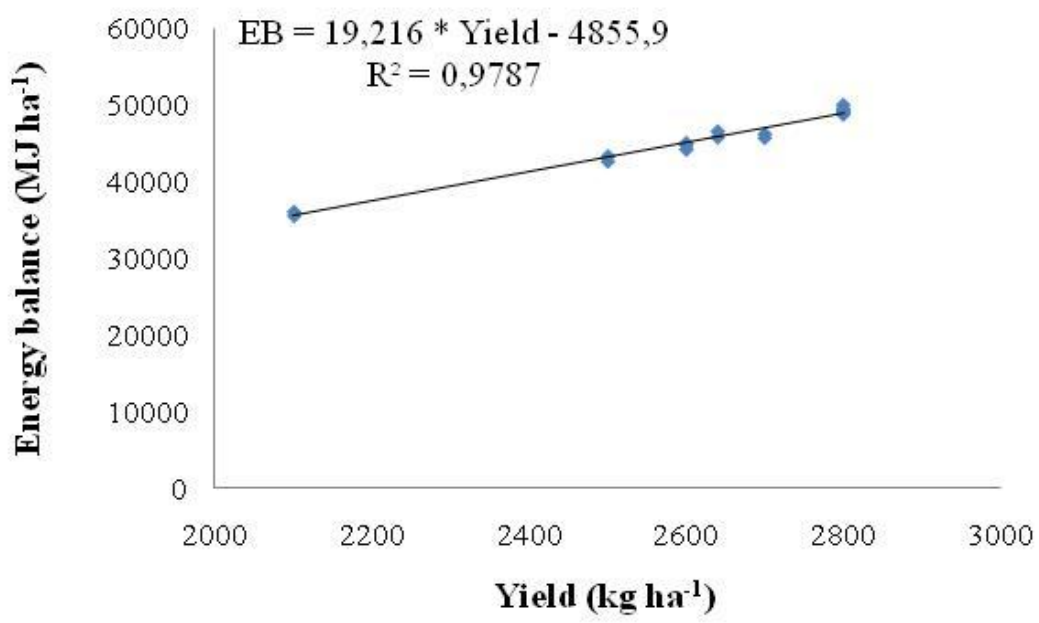

FIGURE 3. Behavior of energy balance due to yield.

\section{CONCLUSIONS}

The analysis of material flows shows the physical reality of production systems but it does not ease the decision making since it brings several distinct inputs that cannot be summed.

GMO crops may present less demand in some inputs being environmentally favorable in the material convergence. This conclusion does not consider broader aspects of GMO in biodiversity or the surrounding ecosystem. 
All evaluated scenarios presented reduction in the use of the majority of the applied agricultural inputs.

Energetically, the majority of the scenarios improved their performance by the use of GMO seeds. Among the regions, the State of Parana (PR) was the most energetically efficient, either in the energy profitability (EROI) or the net energy availability (EB).

The variations in the Energy balance and in the EROI presented high correlation. The energy balance presented correlation with yield, which could be an indirect indicator of net energy availability for the studied scenarios. It is suggested that for other crops and scenarios this analysis could be continued for monitoring the range of this statement.

\section{REFERENCES}

AGRIFNP. 2009: anuário da agricultura brasileira. São Paulo: FNP Consultoria \& Comércio, 2009. $545 \mathrm{p}$.

ANP. NATIONAL OIL AGENCY. Resolution ANP n. 7, 19 de março de 2008. Disponível em: <http://www.anp.gov.br/biocombustiveis/biodiesel.asp>. Acesso em: 28 jul. 2009.

ASAE Standards. D497.4 Agricultural machinery management data. St. Joseph, 2003. ASAE.

CAVALETT, O; QUEIROZ, J.F.; ORTEGA, E. Emergy assessment of integrated production systems of grains, pig and fish in small farms in the South Brazil. Ecological Modelling, Amsterdam, v.19, p.205-224, 2006.

CHAVANNE, X.; FRANGI, J.P. Le rendement énergétique de la production d'éthanol à partir de maïs. Comptes Rendus Geoscience, Paris, v.340, p.263-287, 2008.

DIAZ-BALTEIRO, L.; RODRIGUEZ, L.C.E. Optimal rotations on eucalyptus plantations including carbon sequestration a comparison of results in Brazil and Spain. Foraging Ecololgy and Management, v.229, p.247-258, 2006.

EMBRAPA.EMPRESA BRASILEIRA DE PESQUISA AGROPECUÁRIA. Tecnologia de produção de soja: região central do Brasil. Londrina: Embrapa Soja, 2006. 220 p. (Sistema de Produção, 9).

FERRARO JUNIOR, L.A. Proposição de método de avaliação de sistemas de produção e de sustentabilidade. 1996. 132 f. Tese (Doutorado) - Escola Superior de Agricultura "Luiz de Queiroz”, Universidade de São Paulo, Piracicaba, 1996.

FLUCK, R.C.; BAIRD, C.D. Agricultural energetics. Gainesville: University of Florida, Agricultural Engineering Department and Institute de Food and Agricultural Sciences, 1982. 197 p.

IBGE. INSTITUTO BRASILEIRO DE GEOGRAFIA E ESTATÍSTICA. City Agricultural Research 2007. Disponível em: <ftp://ftp.ibge.gov.br>. Acesso em: 26 maio 2009.

JACOVINE, L.A.G.; VIANA, W.D.; ALVES, R.R.; WALTER, M.K.C.; SILVA, M.L.;

VALVERDE, S.R. Environmental approach of companies within the pulp/paper, metallurgical and sugar/alcohol sectors. Scientia Agrícola, Piracicaba, v.66, n.1, 1-7, 2009.

MASUDA, T.; GOLDSMITH, P. Área plantada, produtividade e projeções em longo prazo. Boletim de Pesquisas em Soja, v.13, p.45-57, 2009.

MOLIN, J.P.; MILAN, M. Trator-implemento: dimensionamento, capacidade operacional e custo. In: GONÇALVES; J.L.M., (Ed). Conservação e cultivo de solos para plantações florestais. Piracicaba: IPEF, 2002, p.409-436.

PELLIZZI, G. Use of energy and labour in Italian agriculture. Journal of Agricultural and Engineering Research, v.52, p.111-119, 1992. 
PIMENTEL, D. Handbook of energy utilization in agriculture. Boca Raton: CRC Press, 1980. $475 \mathrm{p}$.

PIMENTEL, D.; HEPPERLY, P.; HANSON, J.; DOUDS, D.; SEIDEL, R. Environmental, energetic and economic comparisons of organic and conventional farming systems. BioScience, Washington, v.55, p.573-582, 2005.

PIMENTEL, D; PATZEK, T.W. Ethanol production using corn, switchgrass and wood; biodiesel production using soybean and sunflower. Natural Resources Research, v.14, p.65-76, 2005.

PIZZIGALLO, A.C.I.; GRANAI, C.; BORSA, S. The joint use of LCA and emergy evaluation for the analysis of two Italian wine farms. Journal of Environmental Management, London, v.86, p.396-406, 2008.

RANIUSA, T.; EKVALLB, H.; JONSSONA, M.; BOSTDEBT, G. Cost-efficiency of measures to increase the amount of coarse woody debris in managed Norway spruce forests. Forage Ecololgy and Management, Amsterdam, v.206, p.119-133, 2005.

ROMANELLI, T.L.; MILAN, M. Energy balance methodology and modeling of supplementary forage production for cattle in Brazil. Science in Agricultural, University Park, v.62, p.1-7, 2005.

ROMANELLI, T.L.; MILAN, M. Energy performance of a production system of eucalyptus. Revista Brasileira de Engenharia Agrícola e Ambiental, Campina Grande, v.14, p.896-903, 2010 b.

ROMANELLI, T.L.; MILAN, M. Material flow determination through agricultural machinery management. Science in Agricultural, University Aprk, v.67, p.375-383, 2010a.

ROMANELLI, T.L.; COHEN, M.J.; MILAN, M.; BROWN, M.T. Energy synthesis of intensive eucalyptus cultivation in São Paulo, Brazil. Forage Science, v.54, p.228-241, 2008.

SILVA, A.N.; ROMANELLI, T.L.; REICHARDT, K. Energy flow in castor bean (Ricinus communis L.) production systems. Science Agricultural, University Park, v.67, p.737-742, 2010.

TELLARINI, V.; CAPORALI, F. An input/output methodology to evaluate farms as sustainable agroecosystems: an application of indicators to farms in central Italy. Agriculture, Ecosystems and Environment, v.77, p.111-123, 2000.

ULBANERE, R.C.; FERREIRA, W.A. Análise do balanço energético para à produção de milho no Estado de São Paulo. Engenharia Agrícola, Sorocaba, v.4, p.35-42, 1989. 